\title{
DYSFUNCTIONAL ASSOCIATION BETWEEN PUBLIC EXPENDITURE GROWTH AND NATIONAL CONSUMPTION COST: A VECTOR ERROR CORRECTION APPROACH
}

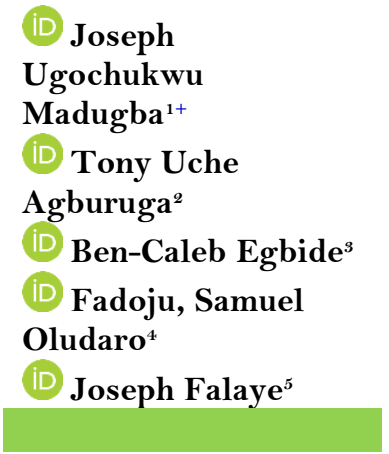

\section{Article History}

Received: 10 September 2020 Revised: 2 September 2021 Accepted: 24: September 2021 Published: 21 October 2021

\section{Keywords}

Capital expenditure

Recurrent expenditure

Consumer price index

Revenue generation

Exchange rate

Nigeria.

\section{JEL Classification:} A10; A19; B13.

\author{
${ }_{1,3,5}$ Accounting and Finance Department, Landmark University, Nigeria. \\ 'Email:Madugba.joseph@lmu.edu.ng Tel:+2348063697038 \\ ${ }^{3}$ Email: ben-caleb.egbide@lmu.edu.ng Tel: +2348035855644 \\ ${ }^{5}$ Email: falaye.joseph@lmu.edu.ng Tel: +8069424466 \\ ${ }^{2}$ Bursary Department, Federal University, Otueke, Nigeria. \\ Email:uchetagburuga@gmail.com Tel: +8033095424 \\ ${ }^{~ D e p a r t m e n t ~ o f ~ F i n a n c i a l ~ S e r v i c e s, ~ L a n d m a r k ~ U n i v e r s i t y, ~ N i g e r i a . ~}$ \\ Email:fadoju.oludare@lmu.edu.ng Tel: +8038383941
}

\begin{abstract}
The management of public expenditure is crucial due to its effect on people's standard of living. In line with this, this study investigated public expenditure growth and national consumption costs using a vector error correction approach. The objective is to determine the effect of capital and recurrent expenditure on the consumer price index. The dependent variable in this study is national consumption measured by the consumer price index, while the independent variable is public expenditure measured by capital and recurrent expenditures. An ex post facto research design was adopted, and data for the study spanning from 1981 to 2019 was sourced from the World Bank. Descriptive statistics, unit root tests, cointegration tests and vector error correction estimates were all conducted with the aid of EViews 9. Based on the results, we concluded that there is a positive but insignificant relationship between the consumer price index and capital and recurrent expenditures of the government in Nigeria. We recommend that Nigeria's government should increase expenditure on projects that will improve the economy and the living standards of the people. Additionally, there is an urgent need for proper monitoring of allocations contained in the budget to ensure efficient and effective utilization of funds, as this will help to improve the standard of living of the people and improve the economy.
\end{abstract}

Contribution/Originality: This study on the dysfunctional association between public expenditure growth and national consumption cost established that there is a positive and significant long-run association between public expenditure and national consumption cost in Nigeria at a $29 \%$ speed of adjustment. This study, apart from being the most current study in Nigeria on this subject, covers the longest period of time and has also reviewed existing theories on this subject and is the only study that has revealed the speed of adjustment of public expenditure growth and national consumption cost.

\section{INTRODUCTION}

Public expenditure is used to describe financial outlay by the government of a nation for its communal needs and wants, such as the provision of infrastructure, security, pensions, etc. Public expenditure is aimed at providing vital commodities and services which have a traceable relationship with national well-being (Udoka \& Anyingang, 
2015). Over the decades, there has been a continuous and rapid increase in government expenditure without a corresponding manifestation in the well-being of the populace. This, however, has posed a divide among scholars and economists.

The Keynesian classical theory has it that public expenditure is an instrument that can be employed with ease to improve the living standard of the people, as affirmed by Iram (1986), but the study by Rebelo (1990) gave an adverse report on public expenditure and economic growth, while Tanzi \& Zee (1997) and Akpan (2011) reported an insignificant association between government expenditure and economic growth.

Gukat \& Ogboru (2017) noted that public spending has been a subject of crucial curiosity to both scholars and macroeconomic policymakers considering its contribution to economic growth and well-being of the people. This explains why governments periodically plan how the resources will be allocated to achieve even development. Every government's capital administration demands that public spending be kept underneath its revenue level, or at least on par with the yearly inflows to avoid a financial deficit. In Nigeria, the reverse has been the case as the incessant and rapid increase in public annual expenditure has not been reflected in the living standard, implying that the expenditures are not being properly directed, have not been released at all, or are being mismanaged by public authorities. Akpan (2005) asserted that public funds in Nigeria are mismanaged, misappropriated, misplaced and even wasted, and this has accounted for the failure in execution of public projects. Aregbeyen (2006), Aruwa (2010), Babatunde (2011), and Usenobong (2011) stated that there is no in-depth rationalization for the increasing volume of public expenditure in Nigeria.

Available statistics showed that the total public expenditure in 2016 was 5858.56 billion naira, which is a $117 \%$ increase of the 2015 public expenditure. The expenditure for 2017 was 6456.70 billion naira, which is an $83 \%$ increase from the previous year; in 2018 there was a $121 \%$ increase, which corresponded to 7813.74 billion naira; and 2019 showed an increase of $24 \%$. Regardless of these increases, it is very disheartening and derogatory to say that the living standard in Nigeria is far below the World Bank's benchmark of one US dollar (\$1) per day, as evidenced by the greater population who are living in abject poverty, lack access to clean water, and suffer from a high rate of unemployment that has escalated crime rate and decreased the literacy rate, among others.

The recent Covid-19 outbreak exposed the inadequacies of Nigeria's health sector, as the government was unable to secure adequate medical equipment, such as ventilators, despite various donations from local and international private and public bodies. Medical experts took to their heels as no one was willing to risk their lives for a country without a plan for its citizens. Even the medical center in the Aso Rock Presidential Villa lacked adequate facilities for months before the emergence of the Coronavirus, so it is not surprising that Nigerian politicians sought medical attention abroad. The inflation rate and exchange rates have again been on the increase leading to depreciation in national savings and value of Nigeria's currency. These problems are of primary concern, which leads to the question of "what is the effect of public expenditure on national consumption in Nigeria?".

\subsection{Gap in Literature}

Extant literature reviews revealed the studies of Lee, Won, \& Jei (2019) and Loizides \& Vamvoukas (2005), but although they were on the same subject, they did not focus on Nigeria. Studies by Udoka \& Anyingang (2015), Agbonkhese \& Asekome (2014) and Efobi \& Osabuohien (2012) were based on Nigeria but they only examined public expenditure and economic growth and did not consider public expenditure growth and national consumption cost. Hence, this study intends to investigate the effect of capital and recurrent expenditure on consumer price index in Nigeria.

\section{LITERATURE REVIEW}

In 1883, Adolph Wagner purported that public costs are compensation for the improvement of a nation. This implies that the provision of public goods and service is a determinant of national consumption. Hence, the theory of 
public spending is based on the theory of costs for the provision of goods and services (Balogun, 2013). While Keynes (1936); Njoku \& Nwaeze (2014) uphold that national development is the upshot of government spending, Egbetunde \& Fasanya (2013) showed that the impact of total public spending on growth is negative by using a bounds testing (ARDL) approach. However, Udoka \& Anyingang (2015) argued that the law of Wagner is only practical for developed nations. For instance, Alm \& Embaye (2010) established that government expenditure is not only prejudiced by per capita income and costs burn-in financing the government but also by fiscal illusion in South Africa. In Nigeria, the studies of Essien (1997); Babatunde (2011); Aregbeyen (2006); Ighodaro \& Oriakhi (2010) and Ifarajimi \& Ola (2017) also established that Wagner's law is not practical for use in Nigeria's case.

However, Bird (1971), as cited in Efobi \& Osabuohien (2012), strongly argued in favor of Wagner's law on three pieces of evidence. He contended that, first, as a nation develops, administrative and security costs of the government will increase; second, that national development will lead to increased provision of social and cultural services; third, that government expenditure will be required to direct and finance national monopolies and guarantee flat functioning of the market forces.

The Peacock-Wiseman displacement theory contends that public expenditure does not have a direct connection with national consumption. The theorists uphold that public spending increases during periods of social, political and economic convulsion. In support of this theory are Sanjeev, De Mello, \& Sharan (2001), who established that public expenditure increases with political disruption or seismic shift.

Regarding the new public management theory, the proponents stated that best means of growing an economy is encouraging private sector participation in the provision of infrastructure. It further stated that government underperforms because its services, though rendered for non-profit purposes, lack any means of monitoring to determine performance. Gruening (2001) opines that this theory emerged in the late 1970s and early 1980s. The United Kingdom, the United States of America, New Zealand and Australia were identified as leading nations in the practice of new public management theory.

Public expenditure theory contends that government expenditure should be guided on efficiency and equity to eliminate instability in the system (Cosimo, Giolli, \& Mele, 2015; Hindrizia \& Myles, 2005; Magazzino, Giolli, \& Mele, 2015; Samuelson, 1955). In Nigeria today, the major cause of turmoil is not huge government expenditure that is unevenly distributed, lack of efficiency and equity in governance, but lack of justification for the increasing public expenditures

Brown \& Jackson (1990), as cited in Ukwueze (2015), opined that public expenditure is categorized into productive expenditure and transfer expenditure. The former includes costs incurred by the acquisition of inputs and includes expenditure on the purchase of equipment and the payment of civil servants' salaries. The latter covers expenditure for which no goods or services exchanged hands at the time of payment, such as scholarship payments and payments made to voluntary and charitable organizations. Economic literature has it that an increase in productive expenditure will necessitate a crowding-out effect of the private sector investment. Dar \& AmirKhalkhali (2002) established a weaker association between an increase in productivity and productivity capital with a larger size of government. This finding corroborated those of Peden \& Bradley (1989).

\subsection{Conditions Necessary for Increasing Public Expenditure}

According to the Institute of Chartered Accountants' Study Pack (2014), the following conditions are to be met before an increase in public expenditure:

1. Any action by the government which increases expenditure should be backed up by (i) an estimate of the budgetary or financial impact in the year it becomes effective and in the two subsequent years; (ii) a statement by the person requesting the expenditure stating that the increase is consistent with the Appropriations Act and Medium-term Expenditure Framework. 
2. The prior budgetary allocation should be completed before granting any advantage or increase of remuneration, and before the creation of posts or the allocation of career structure and admission of personnel.

3. All contracts concerning annual budget execution should comply with the rules and guidelines on (i) procurement and award of contracts; (ii) due process and certification of contracts.

Olayiwola \& Osabuohien (2010) identified the following as the major effects of public expenditure:

1. Economic stability: Public expenditure, being an anti-cyclical tool, can be used to create effective demand thereby stimulating investment activities. In addition, the total demand needs to be regulated so that the demand flows match the supply flows, otherwise the stimulating effect would result in inflationary pressure.

2. Increased production: This can be achieved by creating positive environments for market forces to increase production. Better still, it can be directed towards the creation and supply of input necessary for the thriving of other industries.

3. Economic growth: Economic growth can be employed in several ways. For instance, it can be used to curtail regional disparities, develop social overheads, and create infrastructure for economic growth in terms of communication and transportation facilities, education and training, growth of capital goods industries, etc.

\subsection{Public Expenditure and National Consumption Cost in Nigeria}

Public expenditure (spending) is described as the cost incurred by the government of the collective needs or wants of the populace, such as health care, security, and education, whereas the costs of national consumption, which is a function of public expenditure, involve the use of goods and services by households. The more the government finances the collective needs of the people, the more the living standards of the populace will improve.

In Nigeria, the reverse has been the case owing to a persistent increase in public expenditure without a corresponding improvement in the living standard of the people. For instance, between 1981 and 1991, public expenditure in Nigeria witnessed a 14.64\% increase, and the national consumption cost within the same period was $21.81 \%$. This shows that the two variables did not fare well within this period and it implies that public expenditure has not been positively reflected in the standard of living, which in this study is measured by the consumer price index. Ejaz, Amır, \& Shabbır (2017) found a positive link between public expenditure and economic growth in Pakistan. Abdelkader, Cheikh, \& Sofiance (2017) also found a positive association between public expenditure and prices, employment and consumption cost in Algeria. In Nigeria, the study by Udoka \& Anyingang (2015) affirmed a positive association between public spending and economic development.

\subsection{Empirical Reviews}

Ehikioya, Omankhanlen, Osuma, \& Inua (2020), in a study that spanned from 2001 to 2018 in Africa using data obtained from the World Bank, established that beyond a specific capacity, the short-term association with longterm and external debt would start to have a deteriorating effect on economic growth in Africa. Hence, they suggested that policymakers should implement policies that would lead to sustained long-term economic performance.

Omodero, Egbide, Madugba, \& Ehikioya (2020) employed time series data in a similar study which covered the period from 2000 to 2018 and affirmed that external debt does not improve consumption cost, but aids raising the cost of living in Nigeria.

Lee et al. (2019) examined the affiliation flanked by government spending and economic growth for China and Korea. The study, though robust, failed to identify how it measured the variables, but used a quantile regression model to examine the correlation between economic growth and the functional classification of government expenditure during Xi Jinping's term of office with the application of Barro's theory, which confirmed that China is at the economic stage of new normal and that privatization, liberalization, and deregulation are very present. 
Nwude \& Boloupremo (2018) tested the validity of Wagner's law and Keynes's hypothesis for Nigeria from 1970 to 2014. They established that only Wagner's law is applicable in Nigeria's case considering the coverage of their study.

Babatunde (2018), in his study on government spending on infrastructure and economic growth in Nigeria covering a thirty-seven-year period from 1980 to 2016, found that government spending on transport and communication, and education and health infrastructure had positive effects on economic growth, while expenditure on agriculture and natural resource infrastructure recorded an insignificant association with economic growth.

Kuncoro (2018) studied the effect of government consumption on private expenditure in Indonesia. The study spanned from 1990 to 2012 and adopted the Almost Ideal Demand System (AIDS) model. It found that government expenditure exceeded household consumption, implying that public sector performance is low compared with the private sector.

Abdelkader et al. (2017) examined the effect of public expenditure on prices and employment in Algeria from 2000 to 2012. The results proved tat there is a positive and long-term association between public expenditure and prices, employment and consumption cost.

Gukat \& Ogboru (2017), in their study on economic growth and government expenditure in Nigeria covering the period from 1981 to 2016, produced mixed findings. Social and economic services indicated no appreciable relationship, while the relationship with administrative services was positive and significant. It was further revealed that administrative and social services showed no association, while economic services had a positive association but it was not appreciable.

Ifarajimi \& Ola (2017) examined government expenditure and economic growth in Nigeria. A long run test showed that government expenditure on administration, economic services and exchange rate indicated an appreciable relationship with economic growth. It also revealed that, in the short run, the nominal exchange rate was significant.

Ejaz et al. (2017), in a similar study in which economic growth was measured with GDP and public expenditure was measured with development, health, defense and education expenditures, established that there is a positive association between development and health expenditures and economic growth, but not with defense and education expenditures.

Oladele, Mah, \& Mongale (2017) established that there is a positive and significant link between public expenditure and economic growth in the long run in South Africa. It also showed that the exchange rate has a positive link with economic growth.

Jelilov \& Musa (2016), in a similar study that covered the period from 1981 to 2012 using the ordinary least squares (OLS) technique, affirmed that government expenditure drives economic growth in Nigeria.

Hasnul (2015), in his study covering the period from 1970 to 2014, confirmed that there is a negative link between government expenditure and economic growth in Malaysia. Again, it showed that the housing and development sector expenditure contributed less to economic growth in Malaysia.

Udoka \& Anyingang (2015) examined the impact of public expenditure on economic development from 1980 to 2012. The study employed data obtained from CBN annual publications and established that there is an association between public expenditure and economic development, though it was not stated whether the relationship is in the long run or short run.

Ukwueze (2015) found that the number of receipts and growth rate of national income and private investment considerably influence the size of public expenditure both in the short run and long run. The findings of the study also showed that external and domestic debts appreciably sway the size of government expenditure in the short run.

Hong \& Nadler (2015) examined if political and institutional factors are germane in determining how the US fiscal variables are exaggerated. Their findings showed that strongly built self-governing orientation in the state parliament is appreciably linked with a boost in the apparent risk of the state. Furthermore, the results also showed 
that, controlling for a variety of economic indicators, lofty public sector union attachment, the absence of the right to work laws, and strong collective bargaining rights are significantly connected with an increase in the professed risk of the state and that the right to strike did not have any significant involvement with state bond yields.

In another study, Edame (2014) discovered that the rate of urbanization, government revenue, population density, external reserves, and type of government jointly or individually influence public expenditure on infrastructure in Nigeria.

Oni \& Ozemhoka (2014) investigated the effect of public expenditure on the growth of the Nigerian economy. The study spanned from 1981 to 2011 and found that a positively significant relationship exists between the dependent and independent variables in the study and recommended that regulatory authorities should ensure proper regulations to strengthen the economy.

Půlpánová (2013) examined the understanding of government expenditure in the Czech Republic. The paper concentrated more on the effect of the government's final consumption expenditure on actual final consumption and never made any findings or contributions.

In 2011, Okafor and Eliya investigated the determinants of the growth of government expenditure in Nigeria. The study discovered that population, public debt, total government revenue, and inflation are significant determinants of the growth of public expenditure.

Bose, Haque, \& Osborn (2007), in a study covering 30 developing nations, found that the share of expenditure in GDP is positively related and correlates with economic growth, and the disaggregated level of government expenditure in education is also significant.

From the empirical reviews above, it can be noted that no study on Nigeria has, to the best of the researchers' knowledge, examined the effect of public expenditure on consumption cost in Nigeria. Therefore, this study is designed to fill the gap in the literature and to determine the effect of capital and recurrent expenditure of the government on the consumer price index in Nigeria.

\section{MATERIALS AND METHOD}

The research design adopted for this study is ex post facto (Madugba et al., 2020; Omodero et al., 2020). The study covered government capital and recurrent expenditure over 39 years spanning from 1981 to 2019. Data was obtained from the World Bank. The tested variable in this study is national consumption cost measured by consumer price index, and the predictor variable is public expenditure measured by capital and recurrent expenditure of the Nigerian government for the period under review. A descriptive statistics stationarity test was carried out to establish the property of the variable to enable prediction of future value. A cointegration test was conducted to determine if there is a long linear relationship between the time series variables, and an autoregressive test was also conducted to predict future trend of public expenditure in Nigeria.

\subsection{Model Specification}

This study adopted the model from Madugba et al. (2020) and Omodero et al. (2020); thus:

$$
\begin{gathered}
\mathrm{CPI}_{\mathrm{it}}=f(\mathrm{CPX}, \mathrm{REX}, \mathrm{EXR}) \\
\mathrm{CPI}_{\mathrm{it}}=f\left(\beta \mathrm{O}+\beta_{1} \mathrm{CPX}_{\mathrm{it}}+\beta_{2} \mathrm{REX}_{\mathrm{it}}+\beta_{3} \mathrm{EXR}_{\mathrm{it}}+\mathrm{et}\right)
\end{gathered}
$$

Where CPI = Consumer price index.

$$
\begin{aligned}
& \mathrm{CPX}=\text { Capital expenditure. } \\
& \mathrm{REX}=\text { Revenue expenditure. } \\
& \mathrm{EXR}=\text { Exchange rate }
\end{aligned}
$$


Table 1. Descriptive statistics.

\begin{tabular}{c|c|c|c|c}
\hline Variable & LCPI & LCPX & LREX & LEXR \\
\hline Mean & 1.250797 & 2.168846 & 2.442052 & 1.509917 \\
\hline Median & 1.471302 & 2.489980 & 2.664266 & 2.007310 \\
\hline Maximum & 2.427342 & 3.359645 & 3.844936 & 2.487027 \\
\hline Minimum & -0.310372 & 0.612794 & 0.676767 & -0.209217 \\
\hline Std. Dev. & 0.885060 & 0.875971 & 1.041276 & 0.862061 \\
\hline
\end{tabular}

Evidence from Table 1 indicates that the mean value of the consumer price index is 1.250. This value is positive and implies that there is a relationship between the dependent variable and the predictor variables in the study. This is validated by a standard deviation value of 0.885 . The minimum and maximum values of 2.427 and 0.310 were also indicated for the same variable.

Capital expenditure is shown to have a mean value of 2.168 , implying that capital expenditure influences the consumer price index. This is corroborated by a standard deviation value of 0.875 , which is also positive with minimum and maximum values of 3.359 and 0.612 , respectively.

Statistical evidence from Table 1 also indicates that recurrent expenditure has a mean value of 2.442. Again, this accounts for the influence of recurrent expenditure on CPI. The standard deviation value of 1.041276 was shown with a minimum and maximum value of 3.844 and 0.676 .

From Table 1 there is statistical evidence that the mean value of the exchange rate is 1.509. This, however, means that there is a strong association between CPI and EXR. Further, it is validated by a standard deviation value of 0.862 with minimum and maximum values of 2.487 and -0.209 , respectively.

Table 2. Unit root test (augmented DICKEY-FULLER).

\begin{tabular}{c|c|c|c|c|c}
\hline Variable & Test Statistic & $\mathbf{1 0} \%$ & $\mathbf{5 \%}$ & $\mathbf{1 \%}$ & \multicolumn{2}{|c}{ Order of integration } \\
\hline LCPI & 3.565632 & & $* * *$ & $* *$ & $\mathrm{I}(\mathrm{I})$ \\
\hline LCPX & -6.322965 & $* * * *$ & $* * *$ & $* *$ & $\mathrm{I}(\mathrm{I})$ \\
\hline LREX & -8.309002 & $* * * *$ & $* * *$ & $* *$ & $\mathrm{I}(\mathrm{I})$ \\
\hline LEXR & -5.205054 & $* * * *$ & $* * *$ & $* *$ & $\mathrm{I}(\mathrm{I})$ \\
\hline
\end{tabular}

Granger \& Newbold (1974) and Granger (1986) asserted that the regression coefficient of non-stationary data will be misleading. This study employed the augmented Dickey-Fuller (ADF) unit root test to establish the stationarity of the data variables in our study. Evidence from Table 2 indicates that the time series variables are all stationary at the first difference (i.e., I(I)), meaning that the data is good for further statistical analysis and the results will not be spurious.

Table 3. Unrestricted cointegration rank test (trace).

\begin{tabular}{c|c|c|c|c}
\hline Hypothesized & & Trace & $\mathbf{0 . 0 5}$ & \\
\hline No. of CE(s) & Eigenvalue & Statistic & Critical Value & Prob.** \\
\hline None & 0.395248 & 45.94352 & 47.85613 & 0.0748 \\
\hline At most 1 & 0.301532 & 27.33487 & 29.79707 & 0.0937 \\
\hline At most 2 & 0.183317 & 14.05681 & 15.49471 & 0.0814 \\
\hline At most 3 $*$ & 0.162564 & 6.564170 & 3.841466 & 0.0104 \\
\hline
\end{tabular}

Table 4. Unrestricted cointegration rank test (maximum eigenvalue)

\begin{tabular}{c|c|c|c|c}
\hline Hypothesized & & Max-Eigen & $\mathbf{0 . 0 5}$ & \\
\hline No. of CE(s) & Eigenvalue & Statistic & Critical Value & Prob.** \\
\hline None & 0.395248 & 18.60865 & 27.58434 & 0.4453 \\
\hline At most 1 & 0.301532 & 13.27806 & 21.13162 & 0.4270 \\
\hline At most 2 & 0.183317 & 7.492642 & 14.26460 & 0.4326 \\
\hline At most 3 $*$ & 0.162564 & 6.564170 & 3.841466 & 0.0104 \\
\hline
\end{tabular}




\subsection{Cointegration Test}

To establish a long-run relationship between the data variables in our study, the Johansen cointegration test was adopted. From Table 3, the trace statistics indicate that there is only one cointegration at the 0.05 level (marked *). To further buttress this, the researchers employed the max-Eigen statistic, as shown in Table 4, which also proves that there is a cointegration (marked *), hence, the vector error correction estimate was employed for further analysis in this study.

Table 5. Normalized long-run VEC estimates, and the error correction terms

\begin{tabular}{|c|c|c|c|c|c|}
\hline & LCPI & LCPX & LREX & LEXR & $\mathbf{C}$ \\
\hline & 1 & 0.574683 & 0.265728 & 0.174368 & 0.905856 \\
\hline & - & $(-0.09199)$ & $(-0.09889)$ & $(-0.11439)$ & \\
\hline & - & {$[6.24718]$} & {$[2.68705]$} & {$[1.52437]$} & \\
\hline & $\mathrm{D}(\mathrm{CPI})$ & $\mathrm{D}(\mathrm{CPX})$ & $\mathrm{L}(\mathrm{REX})$ & $\mathrm{L}(\mathrm{EXR})$ & \\
\hline Error & -0.025727 & 0.709790 & 0.136338 & 0.891426 & \\
\hline Correction & $(0.08900)$ & $(0.23116)$ & $(0.21231)$ & $(0.24945)$ & \\
\hline Term & {$[-0.28906]$} & {$[3.07051]$} & {$[0.64217]$} & {$[3.57358]$} & \\
\hline
\end{tabular}

the $\mathrm{z}$ statistics. ${ }^{* *}$ and ${ }^{*} * *$ denote significance at $5 \%$ and $1 \%$, respectively.

\subsection{Vector Error Correction Estimates and Error Correction Terms}

Statistical evidence from Table 5 indicates that the normalized long-run estimates of the national consumption cost (LCPI) is negative and insignificantly impacts public expenditure in Nigeria, meaning that an increase in public expenditure will necessitate an equal increase in national consumption cost and vice-versa. Put differently, it implies that as the government continues to increase its expenditure, more money will be in circulation, which will improve the consumption level if properly regulated and without prejudice regarding whether the expenditure is used for the public interest on projects that can improve the living standard of the people. This finding also corroborates those found in the studies by Gukat \& Ogboru (2017) and Ifarajimi \& Ola (2017).

The lower segment of Table 4 shows the speed of adjustment back to equilibrium in the event of a short-run deviation from equilibrium. The short-run adjustment indicates that the speed of adjustment back to equilibrium is $29 \%$.

\section{CONCLUSION AND RECOMMENDATIONS}

The financial outlay of any nation correlates with the national well-being prevalent in the country. In light of the above, this study investigated public expenditure growth and national consumption cost in Nigeria. The motivation for this study is the incessant increase experienced in Nigeria's public expenditure, as contained in the annual budgets, without a corresponding improvement on the living standard of Nigerians. The study employed capital and recurrent expenditures to measure public expenditure growth, while the consumer price index was used to measure the national consumption cost. The new public management theory and the Peacock-Wiseman displacement theory were adopted and an ex post facto research design was employed. A descriptive statistics unit root test, cointegration test, and vector error correction estimates were carried out, and our findings indicate that there is a positive and significant association between public expenditure growth and the national consumption cost in Nigeria.

\section{RECOMMENDATIONS}

Based on the results of the tests necessary to achieve the objective of the study, we recommend the following:

- The government of Nigeria should direct its expenditures on projects that can improve the economy and the living standards of the people. 
- There is an urgent need for proper monitoring of allocations contained in the budget to ensure efficient and effective utilization of funds.

- The execution of government projects should be monitored progressively.

Funding: This study received no specific financial support.

Competing Interests: The authors declare that they have no competing interests.

Acknowledgement: All authors contributed equally to the conception and design of the study.

\section{REFERENCES}

Abdelkader, B., Cheikh, S., \& Sofiance, M. (2017). The impact of public expenditure on employment and income in Algeria: An empirical investigation. American Journal of Economics, 7(3), 155-161. Available at: 10.5923/j.economics.20170703.06.

Agbonkhese, A. O., \& Asekome, M. O. (2014). Impact of public expenditure on the growth of Nigerian economy. European Scientific Journal, $10(28), 219-229$.

Akpan, N. (2005). Government expenditure and economic growth in Nigeria: A disaggregated approach. Central Bank of Nigeria (CBN) Financial Review, 3(4), 18-21.

Akpan, U. F. (2011). Cointegration, causality and Wagner's hypothesis: Time series evidence for Nigeria, 1970-2008. Journal of Economic Research, 16(1), 59-84.

Alm, J., \& Embaye, A. (2010). Explaining the growth of government spending in South Africa. South African Journal of Economics, 78(2), 152-169. Available at: https://doi.org/10.1111/j.1813-6982.2010.01242.x.

Aregbeyen, O. (2006). Cointegration, causality and Wagner's law: A test for Nigeria, 1970-2003. Central Bank of Nigeria Economic and Financial Review, 44(2), 1-17.

Aruwa, S. (2010). Public finances and economic growth in Nigeria. Paper presented at the Faculty Conference Proceeding.

Babatunde, M. A. (2011). A bound testing analysis of Wagner's law in Nigeria: 1970-2006. Applied Economics, 43(21), 2843-2850. Available at: https://doi.org/10.1080/00036840903425012.

Babatunde, S. A. (2018). Government spending on infrastructure and economic growth in Nigeria. Economic Research, 31(1), 9971014. Available at: 10.1080/1331677X.2018.1436453.

Balogun, O. I. (2013). Theories of public expenditure. Retrieved from: http://strategistng.blogspot.com.ng/2013/02/theoriesof-public-expenditures.html.

Bird, R. M. (1971). Wagner's law of expanding state activity. Public Finance, 26(1), 1-26.

Bose, N., Haque, M. E., \& Osborn, D. R. (2007). Public expenditure and economic growth: A disaggregated analysis for developing countries. The Manchester School, 75(5), 533-556. Available at: https://doi.org/10.1111/j.14679957.2007.01028.x.

Brown, C. V., \& Jackson, P. M. (1990). Public sector economics (4th ed.). Oxford, UK: Blackwell.

Cosimo, M., Giolli, L., \& Mele, M. (2015). Wagner's law and Peacock and Wiseman's displacement effect in European Union countries: A panel data study. International Journal of Economics and Financial Issues, 5(3), 812-819. Available at: https://doi.org/10.1016/0176-2680(90)90054-m.

Dar, A. A., \& AmirKhalkhali, S. (2002). Government size, factor accumulation, and economic growth: Evidence from OECD countries. Journal of Policy Modeling, 24(7-8), 679-692. Available at: https://doi.org/10.1016/s016 1-8938(02)00163-1.

Edame, E. G. (2014). Public infrastructure spending and economic growth in Nigeria: An Error Correction Mechanism (ECM) approach. Journal of Social Economics Research, 1(7), 129-140.

Efobi, U., \& Osabuohien, S. E. (2012). Government expenditure in Nigeria: An examination of tri-theoretical mantras. Journal of Economic and Social Research, 14(2), 27-52.

Egbetunde, T., \& Fasanya, I. O. (2013). Public expenditure and economic growth in Nigeria: Evidence from auto-regressive distributed lag specification. Zagreb International Review of Economics \& Business, 16(1), 79-92. 
Ehikioya, B. I., Omankhanlen, A. E., Osuma, G. O., \& Inua, O. I. (2020). Dynamic relationship between public external debt and economic growth in African countries: A curse or blessing. Journal of Open Innovation: Technology, Marketing and Complexity, 6(88), 1-16. Available at: https://doi.org/10.3390/joitmc6030088.

Ejaz, S., Amır, H., \& Shabbır, M. S. (2017). Public expenditure and its impact on economic growth: A case of Pakistan. Kashmir Economic Review, 26(1), 102-126.

Essien, E. (1997). Public sector growth, an econometric test of Wagner's law. Economic and Financial Review, 35(3), $19-31$.

Granger, C. W. J., \& Newbold, P. (1974). Spurious regression in econometrics. Journal of Econometrics, 2(2), 111-120.

Granger, C. W. J. (1986). Developments in the study of cointegrated economic variables. Oxford Bulletin of Economics and Statistics, 48, 213-227. Available at: https://doi.org/10.1111/j.1468-0084.1986.mp48003002.

Gruening, G. (2001). Origin and theoretical basis of new public management. International Public Management Journal, 4(1), 1-25. Available at: https://doi.org/10.1016/s1096-7494(01)00041-1.

Gukat, B. T., \& Ogboru, I. (2017). An empirical analysis of government expenditure and economic growth in Nigeria. Journal of Economics and Development Studies Published by American Research Institute for Policy Development, 5(4), 122-134. Available at: https://doi.org/10.15640/jeds.v5n4a11.

Hasnul, A. G. (2015). The effects of government expenditure on economic growth: The case of Malaysia. INCEIF, Global University of Islamic Finance.

Hindrizia, J., \& Myles, G. D. (2005). Theories of the public sector (pp. 69-87). Cambridge: MIT Press.

Hong, S., \& Nadler, D. (2015). Social media and political voices of organized interest groups: A descriptive analysis. Paper presented at the In Proceedings of the 16th Annual International Conference on Digital Government Research. ACM, $210-216$.

Ifarajimi, G. D., \& Ola, K. O. (2017). Government expenditure and economic growth in Nigeria: An analysis with dynamic ordinary least squares. International Journal of Academic Research in Business and Social Sciences, 7(5), 8-26. Available at: https://doi.org/10.6007/ijarbss/v7-i5/2869.

Ighodaro, C. A., \& Oriakhi, D. E. (2010). Does the relationship between government expenditure and economic growth follow Wagner's law in Nigeria. Annals of University of Petrosani Economics, 1O(2), 185-198.

Institute of Chartered Accountants' Study Pack. (2014). Institute of chartered accountants of Nigeria study park on public sectyor accounting and finance 2014. United kingdom: Emile Woolf Internatiuonal Bracknell House.

Iram, Y. (1986). Education and urban society. Sage Social Science Collection, 18(4), 462-476.

Jelilov, G., \& Musa, M. (2016). The impact of government expenditure on economic growth in Nigeria. Sacha Journal of Policy and Strategic Studies, 15(2), 15-23.

Keynes, J. M. (1936). The general theory of employment, interest and money. International relation and Security Network 1190. Retrived from: http://etext.library.adelaide.edu.au/k/keynes/john_maynard/k44g/k44g.html.

Kuncoro, H. (2018). The impact of government consumption on the private expenditure in developing countries: The case of Indonesia. Business and Economic Horizons, 4(1), 1-16.

Lee, J. C., Won, Y. J., \& Jei, S. Y. (2019). Study of the relationship between government expenditures and economic growth for China and Korea. Sustainability, 11(22), 1-11. Available at: https://doi.org/10.3390/su11226344.

Loizides, J., \& Vamvoukas, G. (2005). Government expenditure and economic growth: Evidence from trivariate causality testing. Journal of Applied Economics, 8(1), 125-152. Available at: https://doi.org/10.1080/15140326.2005.12040621.

Madugba, J. U., Ben-Caleb, E., Agburuga, T. U., Obadiaru, D. E., Ani, W. U., \& Ben-Caleb, J. O. (2020). Optimal tax behaviour and corporate survival: The Nigerian experience. Research in World Economy, 11(6), 108-118. Available at: https://doi.org/10.5430/rwe.v11n6p 108.

Magazzino, C., Giolli, L., \& Mele, M. (2015). Wagner's law and Peacock and Wiseman's displacement effect in European Union countries: A panel data study. International Journal of Economics and Financial Issues, 5(3), 812-819.

Njoku, R., \& Nwaeze, O. P. (2014). Impact of government expenditure on Nigeria's economic growth (1992-2011). The Macro theme Review, 3(7), 79-87. 
Nwude, E. C., \& Boloupremo, T. (2018). Public expenditure and national income: Time series Evidence from Nigeria. International Journal of Economics and Financial Issues, 8(1), 71-76.

Oladele, M. F., Mah, G., \& Mongale, I. (2017). The role of government spending in economic growth in a Country. Risk Governance \& Control: Financial Markets \& Institutions, 7(2), 140-146. Available at: http://dx.doi.org/10.22495/rgcv7i2c1p2.

Olayiwola, K. W., \& Osabuohien, E. S. (2010). Evaluation of the role of fiscal policy in promoting savings, investment and capital formation in Nigeria. The Journal of Banking and Finance, 1O(1), 26-45.

Omodero, C. O., Egbide, B.-C., Madugba, J. U., \& Ehikioya, B. I. (2020). A mismatch between external debt finances and consumption cost in Nigeria. Journal of Open Innovation: Technology, Market, and Complexity, 6(3), 1-13. Available at: https://doi.org/10.3390/joitmc6030058.

Oni, A. A., \& Ozemhoka, A. M. (2014). Impact of public expenditure on the growth of Nigeria economy. European Scientific Journal, 10(28), 219-229.

Peden, E. A., \& Bradley, M. D. (1989). Government size, productivity, and economic growth: The post-war experience. Public Choice, 61(3), 229-245. Available at: https://doi.org/10.1007/bfo0123886.

Půlpánová, L. V. (2013). Understanding Government consumption. Prague, Czech Republic: University of Economics.

Rebelo, S. (1990). Public policy and economic growth: Developing neoclassical implications. International Journal of Political Economy, 98(5), 126-150.

Samuelson, P. A. (1955). Diagrammatic exposition of a theory of public expenditure. The Review of Economics and Statistics, 37(4), 350-356. Available at: http://www.jstor.org/stable/1925849.

Sanjeev, G., De Mello, L., \& Sharan, R. (2001). Corruption and military spending. European Journal of Political Economy, 17(4), 749-777.

Tanzi, V., \& Zee, H. (1997). Fiscal policy and long-run growth. IMF Staff Papers, 44(92), 179-209.

Udoka, C. O., \& Anyingang, R. A. (2015). The effect of public expenditure on the growth and development of Nigerian economy (1980-2012). International Review of Management and Business Research, 4(3), 823-835.

Ukwueze, E. R. (2015). Determinants of the size of public expenditure in Nigeria. SAGE Open, 5(4), 2158244015621346. Available at: https://doi.org/10.1177/2158244015621346.

Usenobong, A. F. (2011). Cointegration, causality and Wagner's hypothesis: Time series evidence for Nigeria, $1970-2008$. Journal of Economic Research, 16(1), 59-84. 